\title{
Impregnation Effect of Medical Aromatic Plant Extract On The Anatomic Structure of Wood
}

\author{
Hüseyin PEKER*1, Hatice ULUSOY \\ ${ }^{1}$ Artvin Çoruh University, Department of Forest Industry Engineering, Faculty of Forestry, 08000, \\ Artvin/TURKEY. \\ ${ }^{2}$ Muğla Sitkı Koçman Üniversity, Köyceğiz Vocational School, Department of Forestry, 48000, Muğla/TURKEY
}

\begin{abstract}
In since the beginning of history, the global world structure and medicinal aromatic plants in our country have been used in very rich areas (medical, cosmetic, food, spice, agriculture, animal husbandry, spice, paint industry, etc.). New human / environment friendly wood protective materials are being developed, thus efforts are made to create an antioxidant / antibacterial product structure in various areas such as hygienic furniture structure, children's toys, hospitals, etc. It has been reported by the World Health Organization (WHO) that the number of herbs used as medicinal and spice in the world is around 20,000. Preparing extracts from plants and using them as medicine, in China in BC. It dates back to 2700 BC. Rapid depletion of forest resources and exposure to synthetic / chemical effects in the environment in which human beings have lived pose serious threats. The anatomical properties of this material, which was aimed to create a much more organic structure by obtaining extracts $(1 \%, 3 \%)$ of various medicinal and aromatic plants (meadow onion, chives) and bringing it into relationship with borax by double process, were examined and the scale of attachment was determined in relation to this. Due to its anatomical structure, the level of adhesion on spruce wood cross-sectional surfaces was evaluated microscopically and the net dry impregnation amount was calculated. In spruce wood, especially the passage aspiration structure is known to be among the most important elements that make it difficult to hold the material in the impregnation process.
\end{abstract}

Anahtar Kelimeler: Wood anatomy, medicinal aromatic plant, impregnation, human/environmental healty,wood toys.

\section{Tıbbi Aromatik Bitki Ekstraktının Ahşabın Anatomik Yapısına Etkileri}

\section{Öz}

Tarihin başlangıcından beri global dünya yapısı ve ülkemizde tıbbi aromatik bitkiler çok zengin alanlarda (tıbbi, kozmetik, gıda, baharat, ziraat, hayvancılık, baharat, boya sanayii vb ) kullanılagelmektedir. İnsan/çevreyle dost yeni ahşap koruyucu materyaller geliştirilmekte olup ,böylelikle hijyenik mobilya yapısı, çocuk oyuncakları, hastanelerde $\mathrm{vb}$ çok çeşitli alanlarda antioksidant/antibakteriyel ürün yapısı oluşturulmaya çalışılmaktadır. Dünyada tedavi amaçlı ve baharat olarak kullanılan bitkilerin sayısının 20.000 civarında olduğu Dünya Sağlık Örgütü (WHO) tarafindan rapor edilmiştir. Bitkilerden ekstraktlar hazırlanarak ilaç olarak kullanılması, Çin'de M.Ö. 2700 yıllarına kadar uzanmaktadır. Orman kaynaklarının hızı bir şekilde azalması ve insanoğlunun yaşamıs olduğu çevre içerisinde sentetik/kimyasal etkilere maruz kalması ciddi tehditler oluşturmaktadır. Çeşitli tıbbi aromatik bitkilerin (çaşır otu) özüt $(\% 1, \% 3)$ elde ederek ve boraks ile ikili işlemle ilişkiye getirilmek suretiyle çok daha organik bir yapı oluşturulması hedeflenmiş bu malzemenin anatomik özelliklerine bakılmış ve bunla ilişkili olarak tutunma ölçeği belirlenmiştir. Anatomik yapısıitibariyle gerek ladin odunu kesit yüzeylerde tutunma düzeyi mikroskobik olarak değerlendirilmiş ve net kuru emprenye madde miktarı hesaplanmıştır. Ladin odununda özellikle geçit aspirasyonu yapısı emprenye işleminde maddenin tutunmasını zorlaştıran en önemli unsurlar arasında olduğu bilinen bir yapıdır.

Keywords: Odun anatomisi, tıbbi aromatik bitkiler, emprenye, insan/çevre sağlığı, ahşap oyuncaklar.

\footnotetext{
*Sorumlu Yazar (Corresponding Author):

Hüsey in PEKER (Dr.); Artvin Çoruh University, Department of Forest Industry

Engineering, Faculty of Forestry, 08000, Artvin/TURKEY. Tel: +90 (466) 215 2405,

Geliş (Received) : 06.03.2021

Fax: +90 (466) 215 1076, E-mail: hpeker@artvin.edu.tr,

Kabul (Accepted) : 12.05.2021

ORCID: 0000-0002-7771-6993

Basım (Published) : 15.08.2021
} 


\section{Introduction}

Due to the wide variety of structure of wood material (aesthetic, penetrability, etc.), it has taken its place in human life in the historical process. The properties of this material (anatomy, technological features, etc.), which are preferred in various fields, facilitate the usage process. Another feature of wood is its ability to grow together with its being in various areas of the earth. However, excessive cutting in tropical forests endangers the forest resource structure during the process. The reproducibility of wood raw material, despite its cutting, cannot eliminate this threat and does not reduce the poverty level. For the efficient use of raw material wood, its wide variety of properties should be well comprehended. In this way, it will be possible to evaluate the wood types at an optimum level and thus, a wide variety of areas can be created. The most significant point in its use depends on the accuracy of the diagnosis. The determination of the type/species of wood is not only in terms of the taxonomic aspect of the plant, but also has significant place in the various fields of use of wood (commercial dimension, artistic, historical, etc.). The property of wood (physics, chemistry, macro/microscopic etc.) is of great importance in recognition (Doğu et al., 2010).

With It is estimated that there are approximately 1000000 plants in the world today. Nearly 500000 of these species have been identified and named, and as a result of the researches conducted by the World Health Organization (WHO), it has been determined that they consist of medicinal plants used for treatment. The amount of medicinal plants used for treatment in our country is at least 500 (Baytop, 1984). 0It is a very old tradition that medicinal plants started to be used in cure of diseases with the settlement of mankind. In many developing countries, herbal medicines constitute an important part of the culture and traditions in rural communities. Plants have a wide variety of chemical substances that have important biological activities on humans (Njume et al., 2010).

Mankind since its creation to today, has been appliying almost all of its needs such as clothing, shelter, food and fuel from the borders of forests. However, the development of technology, forestry method and forest management today has focused the needs of people obtained from forests only on wood raw materials. In our country, this understanding started to prevail day by day and started to be limited to wood (timber, timber, etc.) production. However, it is an incomparable resource for a healthy life, where many economic and cultural activities such as many herbaceous plants, wild animals, water resources, recreation areas can be carried out together in addition to the tree wealth within the forest areas (Özkan et al., 2014). In various studies, the plant material structure reveals that it can contain a very large amount of phytochemical compounds with very strong antioxidant/antimicrobial activity (Kirca, 2007).

Impregnated wood (biotic/abiotic, etc.) has an important place in the construction industry with its economic, aesthetic appearance, as well as being resistant to factors. Water-based soluble impregnations have increased significantly in railways, sleepers, marine support poles, cooling towers, landscaping, outdoor furniture, and construction structures. Water-based impregnating agents generally destroy the odor structure in treated wood, and a wide variety of surface treatments can be performed after impregnation. It can be easily preferred in places of usage and during transportation (Kartal, 1998).

Rapid decline in forest existence and exposure of human beings to synthetic/chemical effects in the environment they live pose serious threats. The importance of natural plants is increasing day by day as the demand for chemical products is diminishing and people are increasing their demand for natural products. Natural plants are used for food, medicinal, paint, essential oils employed for cosmetics and perfumes, biochemicals (non-edible fats and oils, waxes, gums, latex, dyes, tannins, etc.) (FAO, 2014; Oruç et al., 2019; Ersen, 2020). It is aimed to create a much more hygienic structure by obtaining extract (extract) $(1 \%, 3 \%)$ from the plants of various medicinal aromatic plants (meadow onion, chives) whose antioxidant/anti-bacterial properties of the organic wood have been determined in the literature and bringing it into a double process with boric acid. The various properties of this material have been determined and the place/level of use has been revealed. compared.

\subsection{Literature}

Wood is a porous material, and its pore structure affects its behaviour more than any other characteristics. Knowledge of the pore structure is directly related to the density, permeability, stability, strength, thermal and dielectric properties as well as growth characteristics of wood. Pore geometry and porosity affect several commercial processes, including wood drying, chemical treatment, pulping and bleaching (Forsström, 2004).

The anatomical structure of wood varies among species. In general, wood can be divided into two classes: hardwood and softwood. Hardwood has a relatively complex structure comprising four main cell types, namely 
vessels, fibres, ray parenchyma and axial parenchyma, at $20.60 \%, 15.60 \%, 5.30 \%$ and $1.24 \%$ of the volume, respectively (Almerida and Hernandez, 2007).

Generally, structural properties of wood material; Height increase and age increase are different quantities in the parallel (L: longitudinal) and perpendicular (T: tangent, R: radial) directions to the fibers (Bamber \& Burley, 1983). The fact that these three anatomical quantities have specific functional and effective behavior characteristics directly affects the flow patterns of the protective fluids in the wood material and thus the level of the containment of the protective fluid by the wood material (Comstock, 1970).

According to the technological application, wood material in round or sawn condition; All of its surfaces are impregnated in their natural state (not covered by any covering material in any way). In the entry of the protective liquid into the wood material in this situation by vacuum / pressure application; Of course the L, T, R surfaces will have an effect in combination. However, because each surface exhibits its own behavior tendencies due to quantitative differences, the form and rate of additives for absorption of surfaces necessarily occur at different values for each surface (Wardrop and Davies, 1961). According to numerous studies on the subject, the level of preservative fluid content (permeability); While it always occurs at the highest level in the direction parallel to the fibers, it occurs at a lesser level in the directions perpendicular to the fibers (Comstock, 1970). In terms of permeability, it was determined that the amount of liquid absorption in the direction perpendicular to the fibers, especially in the radial direction, remained at a very low level in the strength-impregnable species such as spruce and fir (Siau, 1971). Therefore, it may be of particular importance to determine the permeability according to the directions at the point of absorption of the protective impregnation material in studies related to the testing of the impregnation process. Accordingly, in order to determine the flow of the protective fluid in all three anatomical directions, some surfaces of the long test pieces shown in Figure 1 should be arranged with a waterproof covering device according to the intended / desired flow direction (Usta et al., 1998).

Since wood is a heterogeneous biomaterial which is easily subject to dimensional changes, environmental and biological attacks, its durability and mechanical strength are not sufficient for long-term end uses. Therefore, researchers have developed various methods to offset these disadvantages. Impregnation of solid wood has been one of the most discussed techniques in the past decade. The wood, including both hardwood and softwood, has been impregnated by many chemicals such as thermosetting resin (epoxy resin, phenol formaldehyde, urea formaldehyde, etc.) or polymeric monomer (methacrylate, acrylates, styrene, unsaturated polyester, etc.), followed by in situ polymerization by radiation or catalystthermal treatment (Zhang et al., 2006).

Tondi et al. (2013)Vacuum time was evaluated by keeping the time of submersion fixed at $24 \mathrm{~h}$. When comparing it can be observed that after application of $20 \mathrm{~min}$ of vacuum, the penetration can be considered complete. Only in the case of the solution with $20 \%$ tannin for pine, the penetration is incomplete, but increase in vacuum time does not improve the impregnation rate. High-potential tannin-based formulations are suitable for a new generation of environment-friendly wood preservatives.

\section{Material and Method}

\subsection{Material}

Spruce wood grown in our country was used in the study. Operations were carried out by cutting in radial direction according to the principles of TS 2470 (1976). Çaşır (Ferula comunis L.) and Borax, whose antibacterial/antioxidant properties were previously determined, were used.

\subsection{Method}

Drying process was carried out until it reached a constant weight level in the period of approximately (1-2 months) in the Artvin Coruh University laboratory. After the drying process, it is brought to the level of dust in the grinders. The powdered plants were weighed $10.26 \mathrm{~g}$, and the extraction was carried out in water for 24 hours at room temperature with shaking stirring and filtering to the specified volume levels with solvent. It was then filtered using filter paper and completed with water to a final volume of $5 \mathrm{~L}$ (Ceylan, 2019).

During the preparation phase of the test samples, fibrous defects, cracks, knots, and background color defects in the samples were paid attenttion to avoid. Samples were prepared with the principles of TS 2470 .

Impregnation was carried out in accordance with the principles of ASTM-D 1413-76 (1984). Vacuum for 45 minutes and diffusion for 45 minutes were applied. In order to prevent the preservative material from being 
affected by wood moisture, the test samples were made completely dry.

The samples were kept in an air-dry environment for a while after the impregnation and diffusion process. Later, they were arranged in a way that they did not touch each other and put into drying-oven. The temperature of the oven was adjusted at $103 \pm 2^{\circ} \mathrm{C}$ and kept for 24 hours and made completely dry. At the end of the period, it was taken out of the drying-oven and its exact dry measurements were made (Baysal, 1994; Akyüz et al., 2019).

After the impregnation process, the amount of material remaining (\% retention) in proportion to the complete dry wood was calculated from the formula (Baysal, 1994).

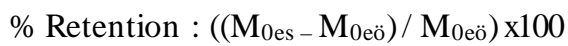

$\mathrm{M}_{0 \text { es }}=$ the weight of the fully dried sample after impregnation (g),

$\mathrm{M}_{0 \text { еӧ }}=$ the weight of the fully dried sample before impregnation (g),

The "Preparation Method" was applied in order to examine the anatomical properties of wood species. For general anatomical measurements, 3 preparation samples were taken from each end of each wood species experiment sample. The wood samples to be taken anatomical sections were boiled in distilled water until completely collapsed in order to soften the wood samples and to remove the air from the tissues. Then the samples were incubated in a 1/1/1 ratio alcohol-glycerine-distilled water mixture until the sections were cut. In addition, crystal acid phenol(Phenol) was added to this mixture in a small amount against the effect of fungi. Sectioning operations were performed in the "Reichert" Slide Microtome from the samples brought to this stage. Longitudinal radial and longitudinal sections 15-20 $\mu \mathrm{m}$ thick were taken from each sample. They were made transparent in sodium hypochlorite for 15-20 minutes and washed with distilled water before being made into continuous preparations. Tye were stained with bile,after washing with distilled water with acetic acid for 1-2 minutes to neutralize the medium. After the painting process, the sections washed thoroughly with distilled water were passed through 50\%, 75\%, 95\% alcohol series, respectively, and the longitudinal radial and longitudinal tangential sections were processed into continuous preparations in glycerin-gelatin with "basic fuchsin" respectively (Bozkurt et al., 1992; Merev, 1998).

\section{Results and Discussions}

The plant extracts of çaşır/chives and borax used in impregnation were prepared at a concentration (1\% - 3\%) and the solution properties are given in Table 1.

Table 1. Solution properties

\begin{tabular}{ccccrrrrr}
\hline \multirow{2}{*}{ Concentration } & \multirow{2}{*}{ Extract /Borax } & \multirow{2}{*}{ Solvent } & \multirow{2}{*}{$\begin{array}{c}\text { Temperature } \\
\left({ }^{\circ} \mathrm{C}\right)\end{array}$} & \multicolumn{2}{c}{ pH } & \multicolumn{3}{c|}{ Density (g/ml) } \\
\cline { 5 - 9 } & & & BI & AI & BI & AI \\
\hline$\% 1$ & Çaşır+Borax & Distiled & \multirow{2}{*}{$22^{\circ} \mathrm{C}$} & 8.10 & 8.10 & 0.990 & 0.992 \\
\hline$\% 3$ & Çaşır+Borax & Water & & 8.75 & 8.75 & 0.990 & 0.990 \\
\hline
\end{tabular}

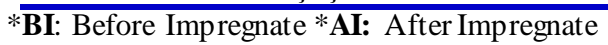

There was no change in solution $\mathrm{pH}$ and density before and after impregnation. It has been reported in the literature that acidic and basic structure affects the technological and otherproperties of wood.

$\%$ Retention values are given in Table 2.

Table 2. \% Retention test results.

\begin{tabular}{|c|c|c|c|c|}
\hline Wood type & Plant Extract /Boraks & $\begin{array}{c}\text { Concentration } \\
(\%) \\
\end{array}$ & $\begin{array}{c}\text { Vacumm/ diffusion time } \\
\text { (min) }\end{array}$ & Retention (\%) \\
\hline Spruce & Çaşır+Borax & $\% 1$ & \multirow{2}{*}{45 Dakika } & 1,12 \\
\hline Wood & Çaşır+Borax & $\% 3$ & & 1,03 \\
\hline
\end{tabular}

The retention value was found to be higher in a $1 \%$ mixture of Çaşır and Borax than a mixture of $3 \%$ Çaşır and Borax.

Baysal et al. (2003) stated that the positive and high level of protection of impregnation depends on the preservative, wood property, retention level (adhesion) and permeability level. 
Örs et al. (2001) The effectiveness of the impregnation process depends on the impregnation material, wood property, retention level (adhesion), permeability level and the anatomical structure depends on the drying/slit opening process, passage aspiration in coniferous wood and tulle formation in leafy trees, storage of various foreign materials creates difficulties in wood impregnation. They reported that the peeling process before starting the impregnation process decreased the free water level in the lumen to $20 \%$ moisture level and thus the depth of impregnation effect increased with drying. Bal (2006) reported that the treatment with ACQ was effective on the mechanical properties and retense was positively affected, providing rapid penetration. Alkan, (2016) impregnated the yellow pine wood with boron compounds and kebracodan, and reported that the highest retention occurred at $1 \%$ concentration. Dişli (2015) published that the highest \% retention at (A12SO4)3 as (9.90\%) and the lowest \% retention at $\mathrm{Ba}$ as (1.07\%) in scotch pine wood and the increase in solution concentration increased the amount of retention. Images of the material retention (anatomical) in various medicinal and aromatic plant extract and borax impregnation in spruce wood are given in Figures 1 and Figure 2.

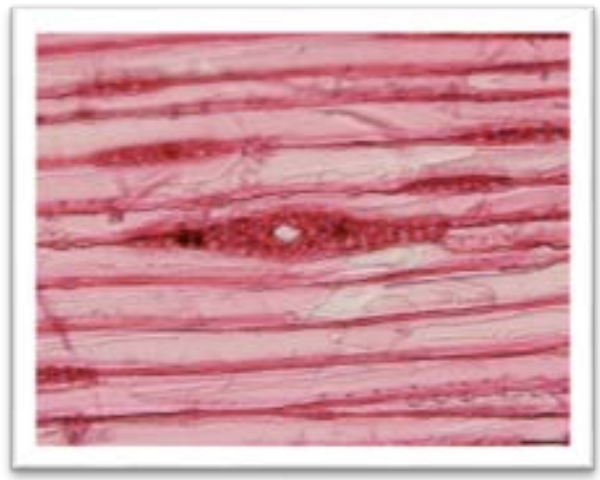

a

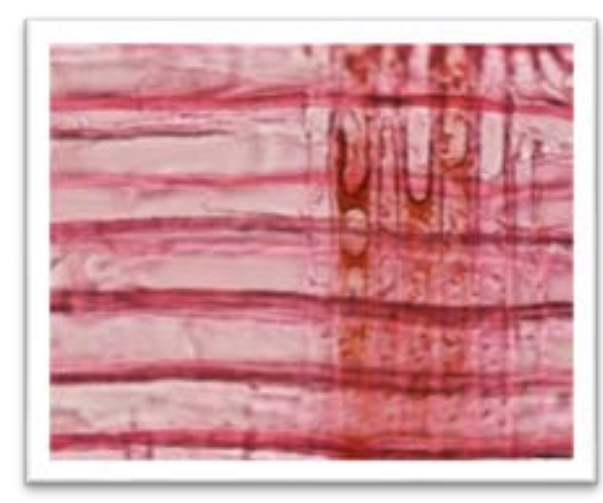

C

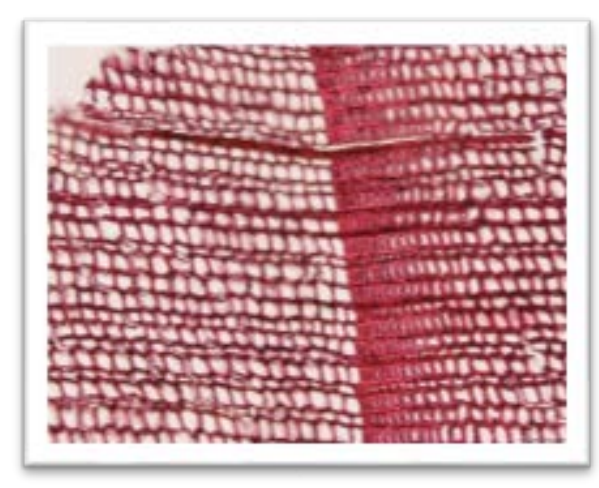

e

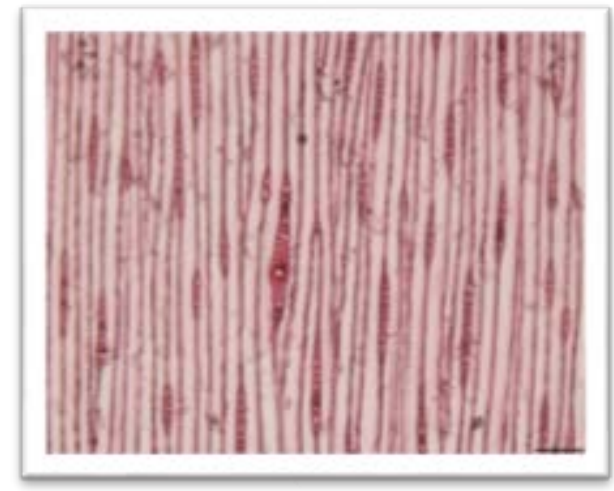

b

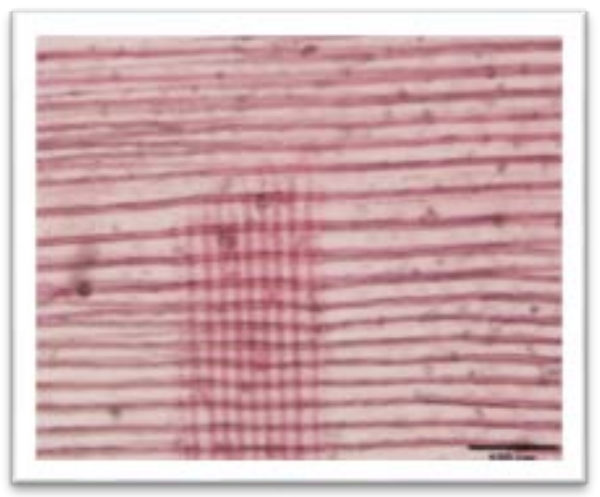

d

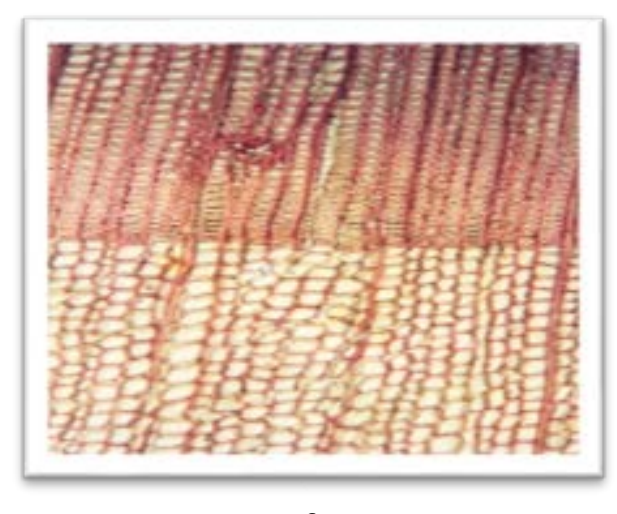

f

Figure 1. Spruce wood impregnated with a 1\% mixture of Çaşır and Borax; tangent section view (a) radial section view (c) cross section view (e) unimpregnated spruce wood; tangent section view (b) radial section view (d) cross section view (f). 
As a result of microscopic examination of preparations prepared from anatomical sections of spruce wood impregnated with a mixture of $1 \%$ Çaşır and Borax; It was determined that the retention occurred in rays, and there was no retention in the traheids. In the tangential (b), radial (d) and transverse (f) section views of the spruce wood control sample and the impregnated spruce wood in tangential (a), radial (c) and transverse (e) directions; Microscopically, it was observed that the best retention was in the tangential section of rays.

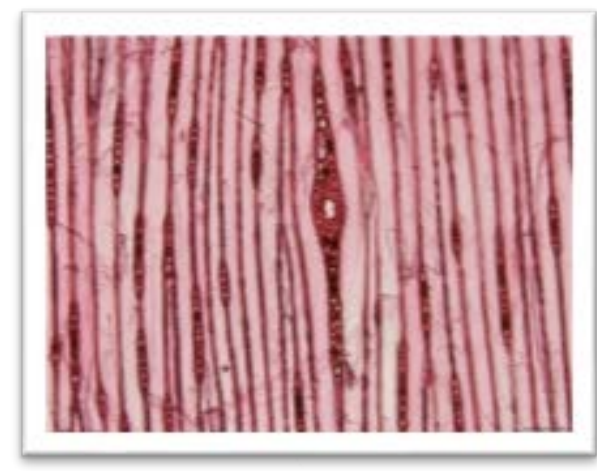

a

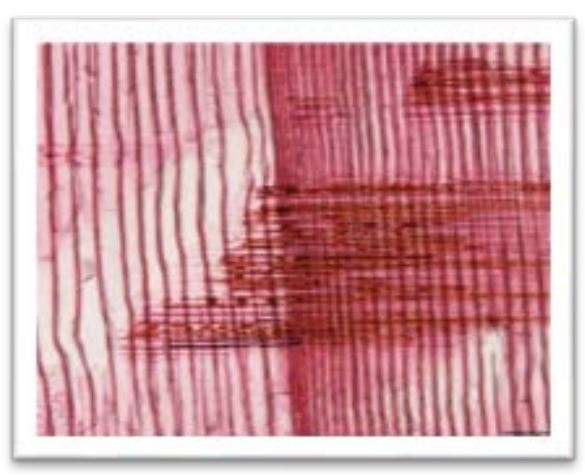

C

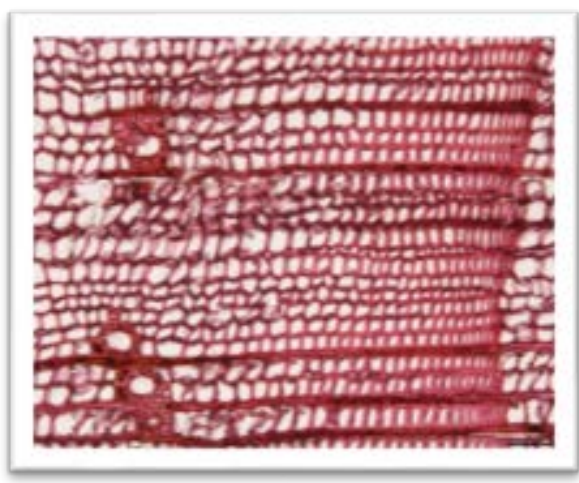

e

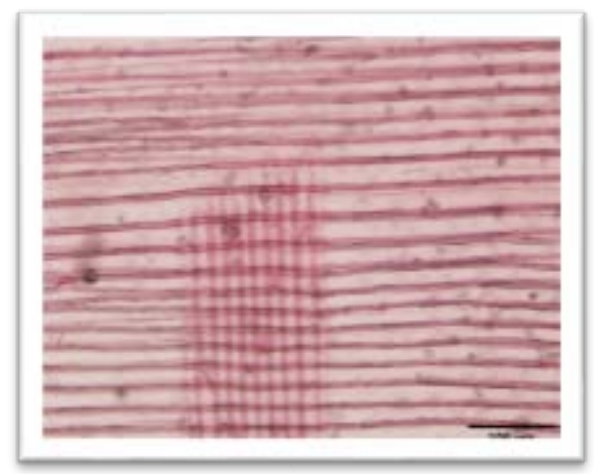

b

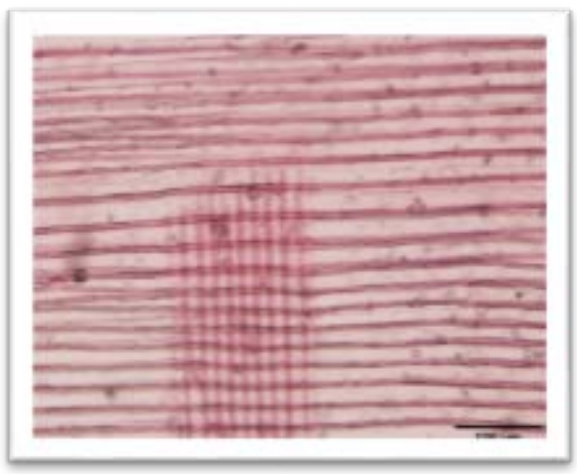

d

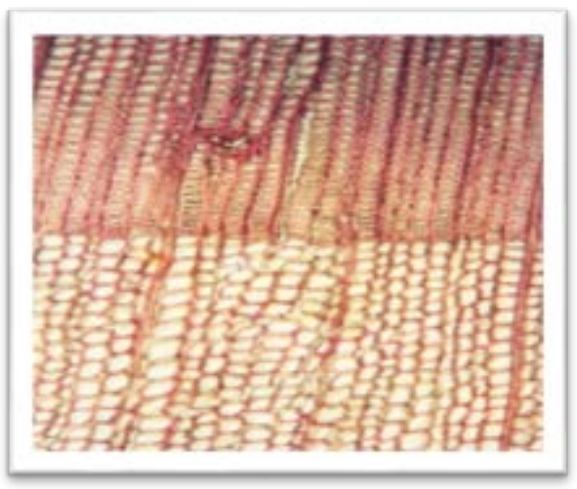

f

Figure 2. Spruce wood impregnated with a 3\% mixture of Çaşır and Borax; tangential section view (a) radial section view (c) cross section view (e) un impregnated spruce wood; tangential section view (b) radial section view (d) cross section view (f).

As a result of microscopic examination of preparations prepared from anatomical sections of spruce wood impregnated with a mixture of 3\% Çaşır and Borax; It has been determined that the retention occurs in the rays and that the traheids do not. In the tangent (b), radial (d) and transverse (f) section views of the spruce wood control sample, the impregnated spruce wood in the tangent (a), radial (c) and transverse (e) sections views; Microscopically, it was observed that the best retention was in the tangentialsection at the rays. As a result of the impregnation with a mixture of $1 \%$ and $3 \%$ Çaşır and Borax; retention was greater in the $1 \%$ mixture of Çaşır and borax. This result is also in parallel with the \% retention values. However, retention occurred in both of the rays, and no retention occurred in the traheids. 


\section{Conclusion and Suggestions}

No significant changes in solution properties, $\mathrm{pH}$ and densities were determined. It can be mentioned that a certain level of retention can create a positive structure in usage areas and technological features. It is obvious that the acidic/basic material planned to be used in addition to the wood type, wood moisture, wood anatomical structure, wood dimensions, preservative/method will significantly affect all technological properties and surface treatment properties of wood. Both the \% retention value structure and the amount of retention material in wood preparations were determined at a very low level. It was observed microscopically that the retention was in the rays and not in the traheit cells.

The rays of the parenchyma cells exist in the rays located in the radial direction in coniferous woods and provide the delivery of nutrients in the radial direction by storing the nutrients. It can be concluded that this feature may have been effective in the intake of the preservative due to the fact that the retention is in the rays and the rays has the task of storing the nutrients. In coniferous trees, passage aspiration occurs especially at the cell wall. The reason for the absence of retention in traheitis may be due to passage aspiration.

The study here compared to various researches, it is the production of new natural surface/impregnation materials that are compatible with human/environmental health and contribute to the country's economy from a wide variety of plant/animal/mineral etc. materials included in our country's resources. Thus, the export of this material to other countries of the world will be provided by country resources will be utilized in the most efficient way. By moving away from chemical/synthetic surface and impregnation materials, providing healthy and hygienic materials has come to the fore. Medicinal aromatic plants and other plant varieties have been appplied in a wide variety of areas that humanity needs, besides being for treatment purposes both in our country and other countries since the beginning of history. Today, these plants are used in the perfumery industry, food additives, condiments, and a wide variety of natural oils. In addition, when human/environmental health is taken into consideration, the use of these plants in products such as furniture (indoor/outdoor), paper industry, wooden toy industry, park/garden furniture etc. contributes to the creation of a hygienic structure.

Especially the vacuum method is preferred but pressurized, dip, brush applications, etc. other methods can be also applied. A wide variety of concentrations and solvents (methanol extracts. Ethanol, acetone, ether and water) can be tried. A wide variety of other plants or resin derivatives in the processes can be applied. By bringing it into relationship with boron and boron derivatives, prolongation of wood life and fire effects can be investigated. The same analyzes can be made on the same species grown in other provinces and the results between different provinces can be compared. By comparing the amounts of antioxidants in different solvents of the same type of plants, the solvent with the best activity can be investigated.

\section{Acknowledgements}

Part of this article presented at ICOEST-2020 6TH international conference on environmental science and technology, Impregnation. Effect of Medical Aromatic Plant Extract on The Anatomic Structure of Wood,77-82,2020.

\section{References}

1. Akyüz, İ., Ersen, N., Tiryaki, S., Bayram, B.Ç., Akyüz, K.C., Peker, H. (2019). Modelling and comparis on of bonding strength of impregnated wood material by using different methods: artificial neural network and multiple linear regression. Wood Research, 64(3), 483-498.

2. ASTM D 1413-76 (1984). Standartd methods of testing preservatives by laboratory soilblock cultures, annual book of astm standarts: USA Standart.

3. Alkan, E. (2016). Doğal emprenye maddeleri ve borlu bileşikler ile emprenye edilen sarıçam (Pinus sylvestris L.) odununun fiziksel ve mekanik özelliklerinin incelenmesi: Gümüşhane Üniversitesi Fen Bilimleri Enstitüsü Yüksek Lisans Tezi, Gümüşhane.

4. Almerida, G. Hernandez, R. (2007). Influence of the pore structure of wood on moisture desorption at high relative humidities: Wood Material Science and Engineering, 2, 3344

5. Bal, B.C. (2006). Amonyaklı bakır quat (ACQ) emprenye tuzu ie emprenye edilen sarıçam (Pinus sylvestris L.) odununun bazı fiziksel ve mekanik özelliklerinin arastırılması: Kahramanmaras Sütçü Imam Üniversitesi Fen Bilimleri Enstitüsü Doktora Tezi, KahramanMaraş.

6. Baysal, E.(1994). Çeşitli borlu ve wr bileşiklerin kızılcam odununun bazı fiziksel özelliklerine etkisi: Karadeniz Teknik Üniversitesi Fen Bilimeri Enstitüsü Yüksek Lisans Tezi, Trabzon.

7. Baysal, E (2003). Borlu bileşikler ve doğal sepi maddeleriyle emprenye edilen sarçam odununun yanma özellikleri: Erciyes Üniversitesi Fen Bilimleri Enstitüsü Dergisi, Kayseri, 19 (1-2): 59-69 
8. Baytop, T. (1984). Türkiye'de Bitkiler ile Tedavi (in Turkish). İstanbul Üniversitesi Yayınları, No:3255Eczacillk Fakültesi, No. 40, Istanbul.

9. Bozkurt,A.Y.(1992). Odun anatomisi: İstanbul Üniversitesi Orman Fakültesi , Yayın No:3652, Fakülte Yayin No:415, İstanbul.

10. Bamber, R.K. Burley, J. (1983). The wood properties of Radiata pine: Commonwealth Agricultural Bureaux, Slough, (84 pp).

11. Ceylan, Ş. (2019). Işgın Bitki (Antioksidan/antibakteriyel) Özütünün Ahşap Endüstrisinde (Mobilya/İnşaat) Kullanılabilme Olanakları, Artvin Çoruh Üniversitesi, BAP Projesi, Artvin.

12. Comstock G.L. (1970). Directional permeability of softwoods: Wood and Fiber, 1 (4): 283-289.

13. Dişli, B., (2018). Bazı mordan ve verniklerin sarç̧am (pinus sylvestris 1.) odununun teknolojik özellikleri üzerine etkisi: Artvin Çoruh Üniversitesi Fen Bilimleri Enstitüsü, Yüksek Lisans Tezi, Artvin.

14. Doğu, D., Tirak, K., Candan, Z., Ünsal, O. (2010). Anatomical Investigation of Thermally Compressed Wood Panels :BioResources, say15(4), s. 2640-2663.

15. Ersen, N. (2020). Assessment of global competitiveness of non-wood forest products: the case of Turkey. Baltic Forestry, 26(2): 1-8.

16. FAO. (2014). About non-wood forest products. In: Non-wood Forest Products. Food and Agriculture Organization of the United Nations, Rome (Italy), 1 p. Available online at: http://www.fao.org/forestry/nwfp/6388/en/.

17. Forsstro"m J. (2004). Fundamental aspects on the re-use of wood based fibres*Porous structure of fibres and ink detachment. PhD thesis. Trita-FPT Report 2004:37.

18. Kartal, S.N. (1998). CCA emprenye maddeleri ile korunan ağaç malzemenin dayanıklılık, yıkanma ve direnç özellikleri: İstanbulÜniversitesi Fen Bilimleri Enstitüsü Doktora Tezi, İstanbul.

19. Kırca, A., Bilişli, A., Demirel, N.N., Turhan, H. ve Arslan, E (2007). Çanakkale florasındaki bazı tıbbi ve aromatik bitkilerin antioksidan ve antimikrobiyal aktiviteleri: TÜBİTAK Proje No: 1040 292. Çanakkale.

20. Merev, N. (1998). Odun Anatomisi: Cilt 1, Doğu Karadeniz Bölgesinde Doğal Angiospermae Taksonlarının Odun Anatomisi, KTÜ, Orman Fak., KTÜ Genel Yayın No: 189. Fak. Yayın No:27, Trabzon, 1998.

21. Njume, C., Afolayan, A.J., \& Ndip, R.N. (2010). An overview of antimicrobial resistanceand the future of medicinal plants in the treatment of helicobacterpylori infections. Afr. J. Pharm. Pharmacol., 3, 685-699.

22. Oruç, F.Ç.S., Erturan, İ.E, Oruç, D. and Oruç, S.H. (2019). Awareness of medical and aromatic plants in the western Black Sea region. International Journal of Agriculture, Environment and Food Sciences (JAEFS) 3(1): 1-4.

23. Özkan, Z.C., \& Akbulut, S. (2014). Ormancıllk Uygulamaları Ders Notları (in Turkish). Faculty of Forestry, Karadeniz Technical University, Trabzon s:1-2.

24. Örs, Y., Efe,H., Atar,M. (2001). Sarıçam ( Pinus sylvestris Lipsky.) Odununda Emprenye Etme ve Renk Açma İşleminin Vernik Katma Sertliğine Etkileri, G.Ü. Fen Bilimleri Enstitüsü Dergisi, 14, 2, 487-503.

25. Siau, J.F. (1971). Flow in wood: Syracuse University Press, New York, (131 pp.).,

26. TS 2470 (1976). Odunda Fiziksel ve Mekaniksel Deneyler İçin Numune Alma Metodları ve Genel Özellikler, TSE, Ankara.

27. Tondi, G.,Thevenon,MF, Mies,B.,Standfest,G., Petutschnigg,A., Wieland,S. ( 2013). Impregnation of Scots pine and beech with tannin solutions: effect of viscosity and wood anatomy in wood infiltration: Wood Science and Technology volume 47, pages615-626.

28. Usta, İ., Hale, M. (1998): A ğaç malzemenin korunması gerekliliği: Yapı Dünyası, Temmuz (28): 50-53.

29. Wardrop, A.B., Davies, G.W. (1961). Morphological factors relating to the penetrations of liquids into wood: Holzforschung 15 (5): 129-141.

30. Zhang, Y. L., Zhang, S. Y., Yang, D. Q. \& Wan, H. (2006). Dimensional Stability of Wood Polymer Composites: Journal of Applied Polymer Science, 102, 50855094. 